\title{
EVALUATION OF AQUATIC CONTAMINATION IN AN URBAN LAGOON ENVIRONMENT IN A COASTAL REGION IN THE NORTH OF BRAZIL
}

\author{
AVALIAÇÃO DA CONTAMINAÇÃO AQUÁTICA EM UMA LAGUNA \\ COSTEIRA URBANA NO NORTE DO BRASIL
}

\author{
Janderson Bruzaca GOMES ${ }^{1}$; Natália Jovita PEREIRA ${ }^{2}$; \\ Elielma Lima de SOUSA ${ }^{3}$; Denise da Silva Sousa ${ }^{4}$; Tiago de Moraes LENZ \\ Débora Martins Silva SANTOS
}

1. Mestrando do Programa em Recursos Aquáticos e Pesca, Universidade Estadual do Maranhão, UEMA, MA, Brasil. jandersonbruzaca@hotmail.com; 2. Mestranda do Programa em Recursos Aquáticos e Pesca, Universidade Estadual do Maranhão, UEMA, MA, Brasil; 3. Mestranda em Microbiologia Agropecuária, Universidade Estadual Paulista, UNESP, Campus Jaboticabal, SP, Brasil; 4. Graduanda em Ciências Biológicas, Universidade Estadual do Maranhão, UEMA, MA, Brasil; 5. Professor do Instituto Federal do Maranhão, IFMA, Campus Viana, MA, Brasil; 6. Departamento de Química e Biologia/Programa de Mestrado em Recursos Aquáticos e Pesca, Universidade Estadual do Maranhão, UEMA, MA, Brasil.

\begin{abstract}
The quality of water is related to how it is used and how its physical, chemical and biological conditions are evaluated. The use of different evaluation tools can therefore provide accurate data about the environmental quality of aquatic ecosystems. The objective of the present study was to evaluate the aquatic contamination of the Laguna da Jansen Ecological Park in São Luís, in the state of Maranhão, Brazil, using different tools (physical variables, microbiological analysis and erythrocytic and gill alterations in Oreochromis niloticus). The microbiological analysis of the water was based on the identification of the most probable number (MPN) of total and thermotolerant coliforms using a chromogenic and fluorogenic enzymatic substrate test (MUG), while the physical-chemical parameters determined were temperature, $\mathrm{pH}$, turbidity and dissolved oxygen. The fish were captured and then anaesthetized for the blood collect by gill puncture. Blood smear slides were prepared and stained with modified Rosenfeld staining for the evaluation of erythrocyte alterations. For histopathological analysis of the gills, the second left branchial arch was removed from each specimen and fixed in $10 \%$ formaldehyde for 24 hours. These were subsequently decalcified in $10 \%$ nitric acid and histological protocols in paraffin. Large numbers of erythrocyte alterations, notably micronuclei, were identified. Among the most common branchial alterations were lamellar epithelium lifting, blood capillary dilation, aneurysms, and total and partial lamella fusion. The result of the microbiological analysis of the water revealed a quantity of thermotolerant coliforms than is permitted under current legislation. These results indicate that the health of the animals has been damaged, pointing out the poor quality of the water in the Laguna da Jansen.
\end{abstract}

KEYWORDS: Coliforms. Gills. Injuries. Micronucleus. Oreochromis niloticus.

\section{INTRODUCTION}

The use of aquatic organisms as a tool to evaluate environmental quality allows the assessment of the effects of pollutants, as well as the potential toxic consequences following their interaction with the environment (JESUS; CARVALHO, 2008). The condition of such organisms is therefore related to physical-chemical and microbiological parameters.

Aquatic environment bioindicators are widely used in environmental analysis (BOLOGNESIE; HAYASHI, 2011). Research employing different forms of analysis can help identify the effects of contaminants on the health of organisms and the environment (RIBEIRO et al., 2016).
The abiotic parameters associated with microbiological analysis have been successfully used in many environmental quality studies (FONTÚRBEL-RADA, 2005; ALVES et al., 2008; MORESCO et al., 2012; KELLER et al., 2013; OLIVEIRA et al., 2017; SEISDEDO et al., 2017). These tools alone, however, do not allow the identification of the effects of environmental contamination on the biota.

The use of fish as bioindicators can reveal changes to biological organization on a biochemical, cellular, tissue and behavioral level, and these changes can be used as biomarkers of environmental contamination (AMARAL et al., 2006). The mobility and lifestyle characteristics of the fish and their position near the top of the food chain can also 
rlflect disturbances on different scales (FREITAS; SIQUEIRA-SOUSA, 2009).

Among the main biomarkers of contamination are those based on changes at molecular and cellular levels, which provide information about the first signs of stress in the environment (NIGRO et al., 2006).

The use of genotoxic biomarkers has been proposed as a method which can be used in environmental quality assessment, and therefore represents an effective warning tool for measuring biological effects in the environment (CAJARAVILLE et al., 2000).

Histological biomarkers are also widely studied in environmental quality assessment. Organs in direct contact with toxic agents, such as the gills, can indicate changes to the acute or chronic toxic actions of these agents (LINS et al., 2010). The gill epithelium plays an important role in the osmotic and ionic maintenance of fish, and cells that act in such maintenance respond directly or indirectly to environmental factors and the internal changes of the body (BERNET et al., 1999; LUPI et al., 2007).

The objective of the present study was to evaluate the aquatic contamination of the Laguna da Jansen Ecological Park, in São Luis in the state of Maranhão, Brazil, using different tools, physical variables, microbiological analysis and erythrocytic and gill alterations in Oreochromis niloticus.

\section{MATERIAL AND METHODS}

Two samples were collected in the dry season of 2015 and two samples were collected in the rainy season of 2016 for the physical-chemical and microbiological analysis of the water. The samples were taken at the same point in the Laguna da Jansen, at coordinates $2^{\circ} 30^{\prime} 03^{\prime \prime} \mathrm{S}$ and $44^{\circ} 18^{\prime} 17^{\prime \prime}$ W (Figure 1).
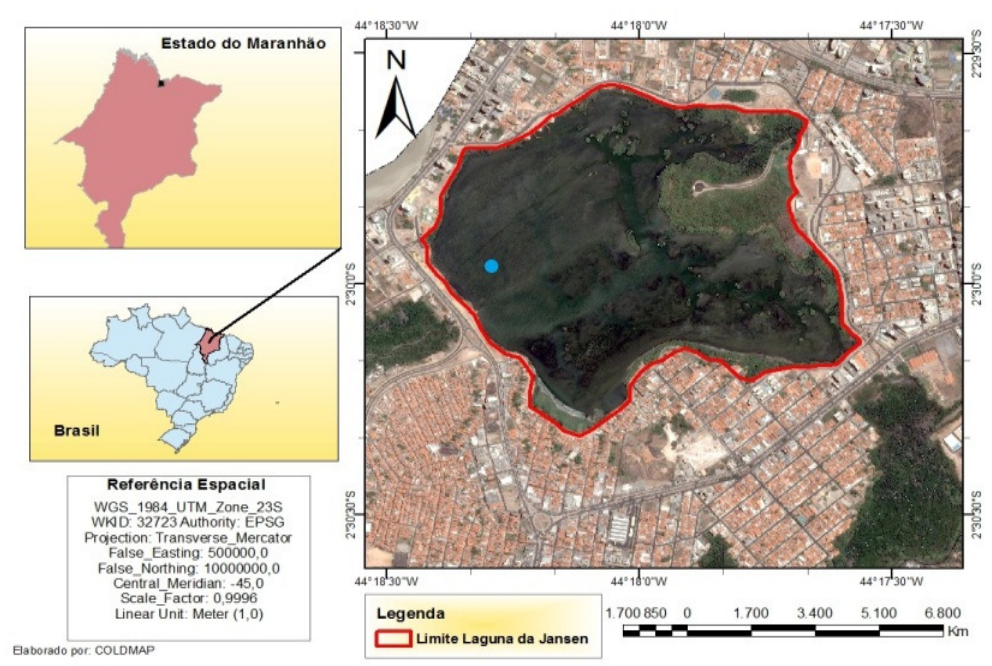

Figure 01. Sample collection area of Laguna da Jansen Ecological Park, São Luís - Maranhão.

Source: Campos (2016).

The analysis of the physical-chemical parameters was carried out in the Cernitas Laboratory LTDA. The $\mathrm{pH}$ was determined electronically, while turbidity and dissolved oxygen were assessed by the titrimetric method. The temperature was registered in situ with a mercury thermometer.

For microbiological analysis, the water samples were taken to the Food and Water Laboratory of the Veterinary Medicine Course of Maranhão State University. The chromogenic (ONPG) and fluorogenic (MUG) enzymatic substrate test, which simultaneously quantifies total and thermotolerant coliforms, was used to determine the most probable number (MPN) of thermotolerant coliforms (APHA, 2005).
A total of 26 specimens of Oreochromis niloticus (Linnaeus, 1758) (Pisces, Cichlidae) were collected with a casting net from the Laguna da Jansen Ecological Park, located in the metropolitan area of São Luís, in the state of Maranhão (Figure 01) between August and December 2015 (dry season). Fish collection was carried out in the dry period only because the species disappeared from the collection area in the rainy season. The fish and water samples were simultaneously collected at the same point.

Blood slides were prepared for erythrocyte analysis after the fish were anesthetized. Blood was collected by gill puncture using disposable insulintype syringes $(1 \mathrm{ml})$. The slides were then prepared using the blood smear technique, dried for 24 hours, 
and fixed and stained with modified Rosenfeld staining at the Animal Morphology Laboratory of Maranhão State University (TAVARES-DIAS; MORAES, 2003).

To evaluate the frequency of micronuclei and other alterations, 2000 cells per fish were analyzed by optical microscopy (100X magnification). The micronuclei were identified in accordance with the criteria proposed by Fenech et al., (2003), and other nuclear abnormalities were identified in accordance with Carrasco et al. (1990).

Following this, the fish samples were stored in ice and each sample was euthanized at the collection site. Thermal shock by freezing consists of submerging the fish in ice water at a temperature of around $5^{\circ}$ to $1^{\circ} \mathrm{C}$ until death. The anesthetic power of such a shock at low temperatures causes the fish to suffer less stress and pain, as well as facilitating the conservation of the organs. It does not interfere with the natural condition of their systems or tissues (ASHLEY, 2007).

For the histopathological analysis of the gills, the second left branchial arch was removed from each sample and fixed in 10\% formaldehyde for 24 hours in the laboratory. The arches were subsequently decalcified in $10 \%$ nitric acid for six hours to facilitate histological sectioning. They were then dehydrated in increasing concentrations of alcohol, diaphanized in xylol, impregnated and included in paraffin. The $5 \mu \mathrm{m}$ thick sections were stained with hematoxylin and eosin (LUNA, 1968) for histological description.

Gill histological alterations were evaluated semi-quantitatively using the Histological Alteration Index (HAI) calculation, adapted from Poleksic and
Mitrovic - Tutundzic (1994), based on the severity of each lesion. The alterations were classified into progressive stages of tissue damage: Stage I alterations, which do not impair the functioning of the organ; Stage II alterations, which are more severe and impair the normal functioning of the organ; and Stage III alterations, which are extremely severe and irreversible.

The HAI value for each fish was calculated using the formula: $\mathrm{HAI}=1 \times \sum \mathrm{I}+10 \times \sum \mathrm{II}+100 \times \sum$ III, with I, II and III corresponding to the number of I, II and III stage alteration, respectively. The mean HAI value was divided into five categories: $0-10=$ normal tissue functioning; $11-20=$ mild to moderate tissue damage; $21-50=$ moderate to severe tissue damage; $51-100=$ severe tissue damage; $>100=$ irreparable tissue damage.

\section{RESULTS AND DISCUSSION}

\section{Physical analysis - water chemistry}

Analysis of physical and chemical parameters is an essential element of monitoring the water quality of an aquatic ecosystem (MATSUZAKI et al., 2004). According to CONAMA Resolution $n^{\circ} 357$ (BRAZIL, 2005), the Laguna da Jansen is characterized as a brackish water body intended to protect aquatic communities and establish a variation in abiotic parameters. The temperature, $\mathrm{pH}$ and turbidity values were within those considered normal by National Environment Council resolution $\mathrm{N}^{\circ}$ 357/2005. The abiotic variables registered in the Laguna da Jansen are shown in Table 01.

Table 01. Abiotic parameters of the water in the Laguna da Jansen and values recommended by CONAMA Resolution n 357 dated March 17, 2005.

\begin{tabular}{cccccc}
\hline Parameters & \multicolumn{2}{c}{$\begin{array}{c}\text { Dry season } \\
\text { (Sept and Nov/2015) }\end{array}$} & \multicolumn{2}{c}{$\begin{array}{c}\text { Rainy season } \\
\text { (Mar and May/2016) }\end{array}$} & $\begin{array}{c}\text { Values } \\
\text { (CONAMA, 2005) }\end{array}$ \\
\hline $\mathrm{pH}$ & 8.28 & 8.30 & 8.11 & 8.18 & 6.5 to 8.5 \\
$\mathrm{DO}\left(\mathrm{mg} / \mathrm{L} \mathrm{O} \mathrm{O}_{2}\right)$ & 2.90 & 0.80 & 3.40 & 3.40 & $\geq 5 \mathrm{mg} / \mathrm{L}$ \\
Turbidity $(\mathrm{NTU})$ & 8.47 & 19.50 & 13.80 & 15.60 & $<100$ \\
\hline
\end{tabular}

The dissolved oxygen level, however, was below the values recommended by the aforementioned resolution. According to Von (1996), dissolved oxygen is the main parameter of the characterization of the effects of water pollution from organic waste. Latuf (2004), meanwhile, emphasized that dissolved oxygen is an important parameter for analysis, as all aerobic aquatic organisms depend on such an element.

The decrease in the dissolved oxygen values of the Laguna da Jansen may therefore indicate pollution and increased organic matter decomposition, affecting the physiology of the aerobic organisms in this aquatic environment.

\section{Microbiological analysis of water}

The results of the microbiological tests of the water of the lagoon revealed the presence of thermotolerant coliforms (Table 2). 
Table 02. Most Probable Number (MPN) of thermotolerant coliforms per $100 \mathrm{~mL}$ of water sampled from the Laguna da Jansen and value recommended by CONAMA Resolution $\mathrm{n}^{\circ} 357$ for brackish water dated 17 March 2005.

\begin{tabular}{|c|c|c|c|}
\hline $\begin{array}{l}\text { Parameter } \\
\text { MPN/100ml }\end{array}$ & $\begin{array}{c}\text { Dry period } \\
(\text { Sept and Nov/2015) }\end{array}$ & $\begin{array}{c}\text { Rainy period } \\
\text { (Mar and May/2016) }\end{array}$ & $\begin{array}{c}\text { Values } \\
\text { (CONAMA, 2005) }\end{array}$ \\
\hline Thermotolerant coliforms & 515 & 24.196 & $<1.000$ \\
\hline
\end{tabular}

The data obtained in the present study shows that the amount of thermotolerant coliforms (Escherichia coli) ranged from 489 to $24,196 / 100$ $\mathrm{ml}$, with the highest concentration obtained in the rainy season. According to CONAMA Resolution 357 dated March 17, 2005, of the National Environmental Council, the analyzed water samples exhibit poor hygienic-sanitary quality for Escherichia coli during the rainy season, and do not meet the standards defined by current legislation.

The presence of coliforms in the water appeared to be directly related to the intensity of the rainfall. Higher rainfall appears to be related to the amount of human and animal excreta carried into the Laguna da Jansen, probably via untreated sewage, thus explaining the higher concentration of thermotolerant bacteria in the lake in the rainy season.

Bastos et al., (2006) stated that increasing urbanization around the Laguna da Jansen Ecological Park increases the volume of waste released into the watercourse, often without proper treatment, resulting in the elevation of the organic load content and the multiplication of microorganisms.

\section{Erythrocyte alterations}

Erythrocyte analysis revealed erythrocytic alterations, mainly micronuclei, for all samples of the Oreochromis niloticus species, as shown in Table 03.

Table 03. Mean and standard deviation of frequency of altered erythrocytes and other nuclear alterations in Oreochromis niloticus in dry period (September and November 2015).

Genotoxic alterations

\begin{tabular}{cccccc}
\hline $\begin{array}{c}\text { Sample } \\
\text { (Sept and Nov/2015) } \\
\mathrm{N}=26\end{array}$ & Micronuclei & Notched & Lobed & Blebbed & Binuclear \\
\hline 1 & $4.33 \pm 2.10$ & $1.83 \pm 1.21$ & $0.66 \pm 3.18$ & $0.91 \pm 3.49$ & $0.5 \pm 3.37$ \\
\hline 2 & $1.64 \pm 1.32$ & $2.57 \pm 1.41$ & $0.5 \pm 1.41$ & $2.35 \pm 1.51$ & $0.42 \pm 2.28$ \\
\hline
\end{tabular}

N: number of specimens sampled

The occurrence of micronuclei and other nuclear substances can be considered a warning of structural or numerical chromosome anomalies caused during cell division (CARRANO; NATARAJAN, 2002). The presence of micronuclei in the sampled fish reflects a complex response to the aggressive agent by the physiological defense mechanism of the microorganism (MERSCH et al., 1996).

According to Bombail et al. (2001), an increase in the frequency of micronucleate cells is a marker of genotoxic effects, which may reflect exposure to different toxic agents. The frequency of micronuclei found therefore suggests that the individuals of the studied species have been affected by the action of a genotoxic agent, impairing their physiological mechanism.

An average of 2.88 micronuclei per fish was observed in the erythrocytes of Oreochromis niloticus, with an average of 4.33 in the dry season sample.

Souza and Fontanetti (2006), when analyzing field studies, established a baseline MN frequency of $0.65 \%$ for $O$. niloticus. In similar studies, Russo et al., (2004) and Bortoluci et al. (2015) identified micronuclei as a response to xenobiotic action in other fish species and at other sites. Russo et al., (2004) evaluated biological damage in Gambus holbrook and found an average of 1.2 micronuclei. Bortoluci et al., (2015) found 3.5 micronuclei per specimen when evaluating the genotoxicity of the elements present in the water of a Brazilian stream.

Oreochromis niloticus has been used and is considered a bioindicator for the evaluation of environmental quality in many studies due to its established ecological characteristics and wide geographic distribution (ARIAS et al., 2007; 
SOUZA; FONTANETTI, 2007). In the Tietê River in the state of São Paulo, sediment increase induced significantly higher micronucleus frequencies in erythrocytes of indigenous tilapia sampled from highly contaminated sites (ROCHA et al., 2009). Micronuclei frequencies in the peripheral blood of Nile tilapia and African catfish were significantly higher in fish collected from highly polluted sites than in clean locations along the River Nile in Egypt
(OSMAN et al., 2011). A significant increase in micronucleus frequency was observed in erythrocytes of Nile tilapia collected from the polluted sections of Lake Qaroun in Egypt in comparison with those from the reference site (OMAR et al., 2012). Normal and altered erythrocytes of Oreochromis niloticus are shown in Figure 02.

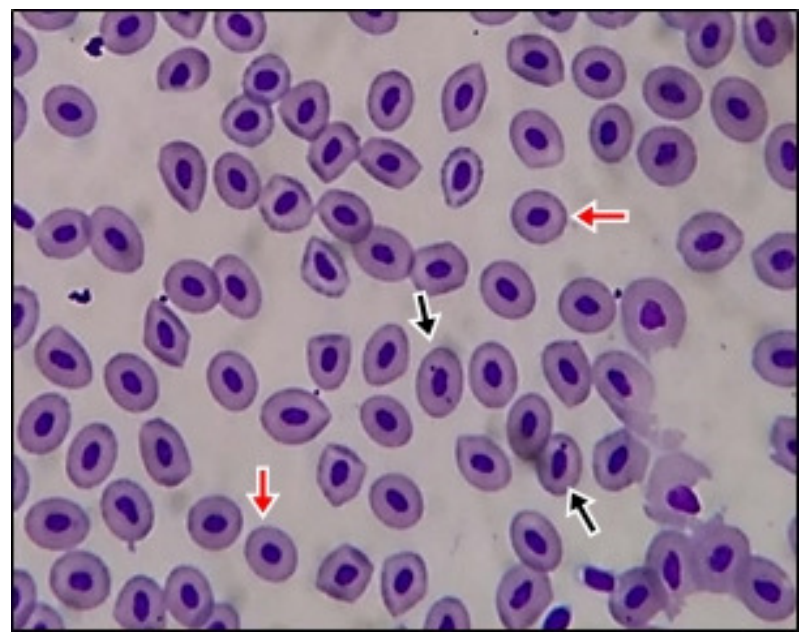

Figure 02. Normal cells (red arrows) and Micronuclei (black arrows) in Oreochromis niloticus erythrocytes. Rosenfeld. Magnification 100x.

Matsumoto et al., (2006) found that the presence of nuclear abnormalities is related to effluent discharge, meaning that aquatic environments receiving domestic or industrial effluents without proper treatment have a higher frequency of cellular abnormalities. As the Laguna da Jansen is known to have a history of effluent contamination (PEREIRA et al., 2014), the frequency of nuclear alterations was considered high for the species studied when compared with the baseline $O$. niloticus $\mathrm{MN}$ frequency established by Souza and Fontanetti (2006) and that found by Bortoluci et al. (2015) in a contaminated area.

These nuclear abnormalities are frequently observed in fish erythrocytes due to their exposure to chemical, toxic, genotoxic, mutagenic or carcinogenic contaminants in the environment (PALHARES; GRISOLIA, 2002; MATSUMOTO et al., 2006). Grisolia et al., (2009), in a study of different fish species from Lake Paranoá in Brasilia, found a higher frequency of micronuclei and binucleate cells in Oreochromis niloticus. Studies have shown that significant micronuclei frequency may reflect the occasional genotoxic effects of increased urbanization and agricultural activities in the area, combined with unknown diffuse pollution sources (DALZOCHIO et al., 2017).

The micronucleus test for the biomonitoring of aquatic environments has been used by several authors in different species due to its practicality and effectiveness. Bombail et al., (2001) applied the test in Pholis gunnellus along a pollution gradient in the Firth of Forth, Scotland, UK; Galindo and Moreira (2009) used it on species of tropical marine fish (Bathygobius soporator); and Galindo et al., (2012) evaluated the potential of sewage to cause genetic alterations in blood cells in Bathygobius soporator populations from the coast of Salvador, Bahia, Brazil.

\section{Branchial Alterations}

The gill lesions observed in the Oreochromis niloticus specimens collected are shown in Figure 3. 


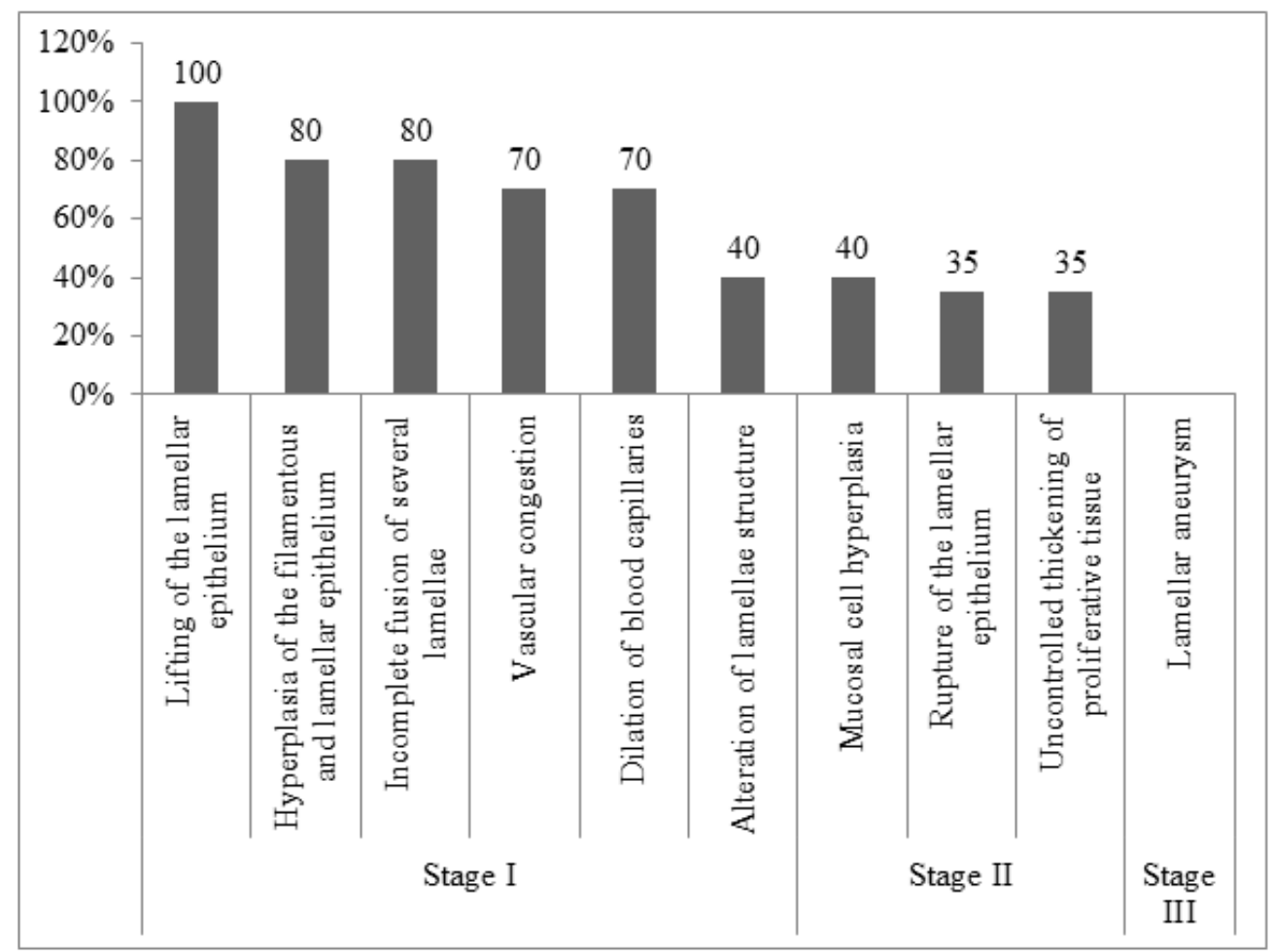

Figure 3. Percentage of branchial alterations in Oreochromis niloticus specimens collected in the Laguna da Jansen in the dry season.

The Histological Alteration Index (HAI) per individual ranged from 10 to 137 , with a mean of 58.6, meaning that the gills of the individuals sampled from Oreochromis niloticus exhibited severe tissue alterations. Although the presence of serious lesions was confirmed, some specimens had a very high index of histological alteration, classified as irreversible damage.

Among the branchial alterations found, there was a prevalence of hyperplasia, epithelial lifting and lamellar fusion (Figure 4).

The same changes prevailed in the study by Dalzochio et al. (2017) of native fish from southern Brazil. Thophon et al. (2003) stated that the lamellar epithelium exhibits the first signs of gill pathology, characterized by lifting away from the pillar cell system, thereby increasing the distance between the external environment and the blood, impairing respiratory function.

The secretion of mucus by the mucosal cells in the gills is known to be a defense mechanism against toxic substances (BOSI et al., 2005, COVELLO et al., 2009, MARCATO et al., 2014). Mucosal cell proliferation has been observed in different species of fish exposed to metal and herbicide contamination in situ (PAULINO et al., 2012; 2014).

Hyperplasia is an initial response of the gill apparatus, characterized by an increase in the functioning of cells and tissues caused by altered physiological activities (SMART, 1976). Different stressors, such as ammonia, phenols, parasites, infectious microorganisms and effluents from domestic and industrial sewage may cause alterations such as hyperplasia and epithelial detachment (NOGUEIRA et al., 2008).

Of the total of sampled individuals, 35\% exhibited a lamellar aneurysm, which is a stage three abnormality (irreversible damage), indicating the exposure of these individuals to severe environmental stressors. According to Hinton and Laurém (1990), the origin of an aneurysm is related to the depletion of the pillar cell system, which impairs vascular integrity through the release of large amounts of blood, pushing the lamellar epithelium outwards.

Cantanhêde et al. (2014), in a histological biomarker study using gills of the Centropomus undecimalis species from the Laguna da Jansen, found gill alterations which were classified as moderate to severe. Most of the histological changes observed in the present study, such as epithelial cell hypertrophy and hyperplasia, epithelial lifting and mucosal cells, lamellar fusion and aneurysms, can be interpreted as nonspecific responses to stress and have been described in fish exposed to a broad spectrum of pollutants (LUKIN et al., 2011). 


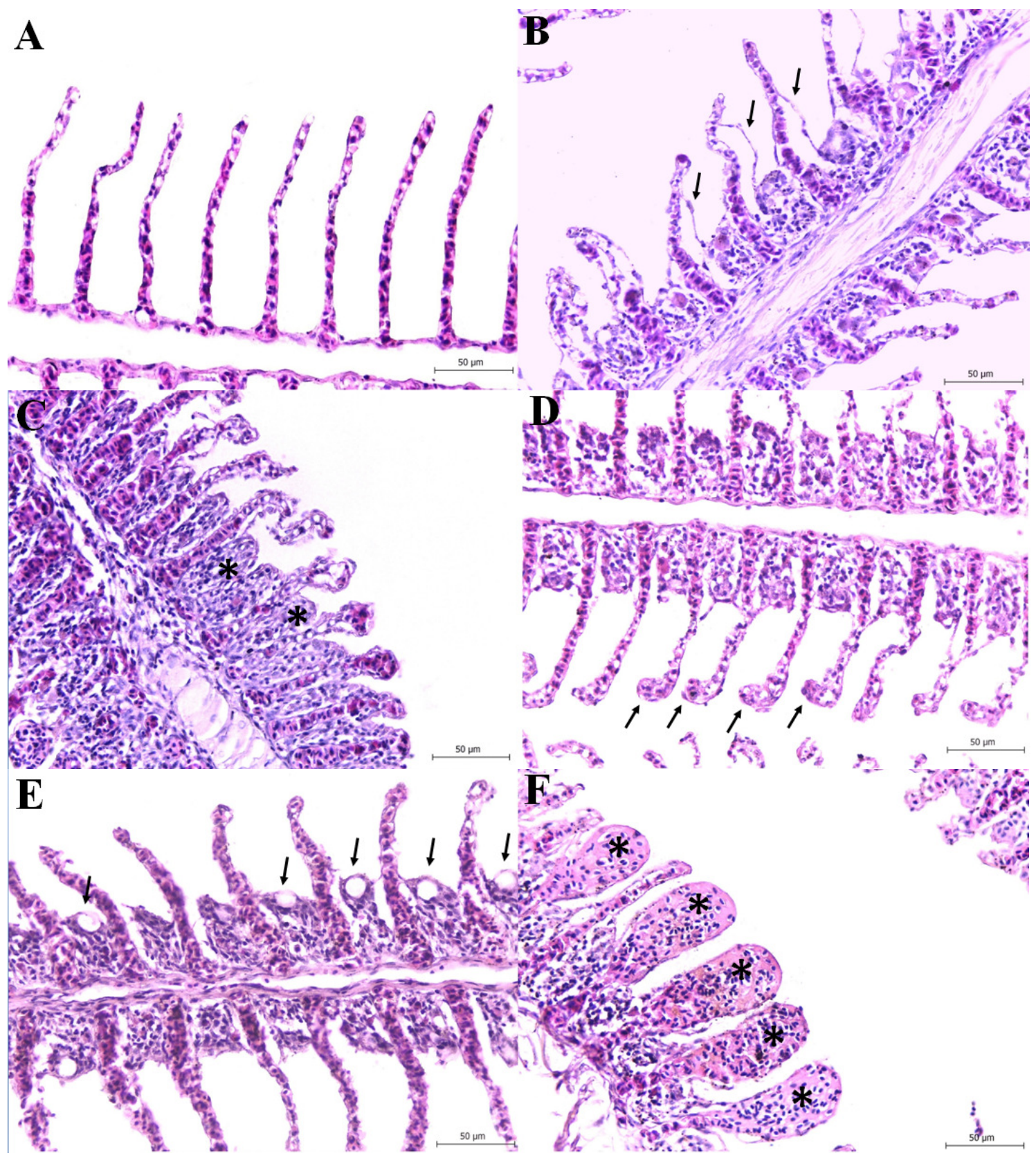

Figure 4. Photomicrograph of gills of $O$. niloticus collected from the Laguna da Jansen Ecological Park, São Luís, Maranhão; In A, a normal unchanged secondary lamella was observed; in $\mathbf{B}$, there is lifting of the lamellar epithelium; in $\mathbf{C}$ hyperplasia of the filamentous and lamellar epithelium (*) with incomplete fusion of several lamellae; in $\mathbf{D}$ congestion of blood vessels; in $\mathbf{E}$ mucosal cell hyperplasia; while in $\mathbf{F}$ there is a warning of aneurysm (*). Magnification 400X, Staining in HE.

The results of the present study corroborate earlier findings by suggesting that the organisms of the Oreochromis niloticus species from this aquatic environment have been exposed to pollutants, including those with genotoxic potential, causing individuals to develop health problems that lead to erythrocytic and branchial abnormalities. The water of the Laguna de Jansen is poor in quality.
Given that the Laguna da Jansen Ecological Park represents an important aquatic ecosystem located in the urban region of São Luís, in the state of Maranhão, the findings of the present study can assist biomonitoring programs for the management of the area, since methodologies using fish biomarkers have numerous advantages, such as their speed of use and low cost. 
All the parameters discussed here are required for a more complete and detailed view of the reality of the water body. The water analysis data, together with the biomarkers, highlights the state of contamination of the Laguna da Jansen.

All the abnormalities found in the present study indicate the presence of contaminants in the ecosystem of the individuals studied, with the level of harm depending on the time of exposure and trophic level (BRITO; LUZ, 2015).

The micronucleus test, using Tilapia fish (Oreochromis niloticus), proved to be a quick and practical test for the monitoring of the pollution of aquatic environments. There was a high frequency of micronuclei in the fish analyzed from the Laguna de Jansen, and the physical-chemical and microbiological data revealed the presence of polluting substances capable of causing damage to the genetic material of the fish living in this aquatic environment.

However, further studies are necessary to establish the micronuclei frequency reference values of fish from different species in the Laguna da Jansen. In this way, erythrocytic and gill alterations in $O$. niloticus can be validated as biomarkers for the aquatic contamination of the lagoon.

\section{ACKNOWLEDGEMENTS}

We would like to thank the Universidade Estadual do Maranhão (Maranhão State University) and FAPEMA for financial support, and the research group (GpBioAqua) for their contributions.

RESUMO: A qualidade da água está relacionada ao tipo de uso da água e à avaliação de suas condições físicas, químicas e biológicas. $\mathrm{O}$ uso de diferentes ferramentas pode, portanto, fornecer dados precisos sobre a qualidade ambiental dos ecossistemas aquáticos. O objetivo do presente estudo foi avaliar a contaminação aquática do Parque Ecológico Laguna da Jansen, em São Luís, no estado do Maranhão, utilizando diferentes ferramentas (variáveis físicas, análises microbiológicas e alterações eritrocíticas e branquiais em Oreochromis niloticus). A análise microbiológica da água envolveu a identificação do número mais provável (NMP) de coliformes totais e termotolerantes utilizando um teste enzimático cromogênico e fluorogênico (MUG), enquanto a análise dos parâmetros físico-químicos determinou temperatura, pH, turbidez e oxigênio dissolvido. Os peixes foram capturados e em seguida anestesiados para coletada do sangue por punção branquial. As lâminas de esfregaço de sangue foram preparadas e coradas com coloração de Rosenfeld modificado para a avaliação das alterações eritrocitárias. Para análise histopatológica das brânquias, o segundo arco branquial esquerdo foi removido de cada espécime e fixado em formaldeído a 10\% por 24 horas. Esses foram subsequentemente descalcificados em ácido nítrico a $10 \%$ e foram realizados protocolos histológicos em parafina. Alterações eritrocitárias, notadamente micronúcleos, foram identificadas em grandes quantidades. Entre as alterações branquiais mais comuns foram a elevação do epitélio lamelar, dilatação capilar sanguínea, aneurismas e fusão total e parcial da lamela. O resultado da análise microbiológica da água revelou uma quantidade de coliformes termotolerantes maior do que é permitido pela legislação vigente. Esses resultados indicam que a saúde dos animais foi danificada, apontando a má qualidade da água na Laguna da Jansen.

PALAVRAS-CHAVE: Brânquias. Coliformes. Lesões. Micronúcleo. Oreochromis niloticus.

\section{REFERENCES}

ALVES, E. C.; SILVA, C. F.; COSSICH, E. S.; TAVARES, C. R. G; SOUZA-FILHO, E. E.; CARNIEL, A. Avaliação da qualidade da água da bacia do rio Pirapó - Maringá, Estado do Paraná, por meio de parâmetros físicos, químicos e microbiológicos. Acta Scientiarum. Technology. 30 (1): 39-48, 2008. https://doi.org/10.4025/actascitechnol.v30i1.3199

AMARAL, A.; SOTO, M.; CUNHA, R.; MARIGÓMES, I.; RODRIGUES, A. Bioavailability and cellular effects of metals on Lumbricus terrestres in habiting volcani soils. Environmental Pollution, v. 142, p. 103108, 2006. https://doi.org/10.1016/j.envpol.2005.09.011

APHA - American Public Health Association. Standard Methods for Examination of Water and Wastewater. 21 th Ed. Washington, DC: APHA, 2005. 
ARIAS, A. R. L.; BUSS, D. F.; ALBUQUERQUE, C.; INÁCIO, A. F.; FREIRE, M. M.; EGLER, M.; MUNGNAI, R.; BAPTISTA, D. F. Utilização de bioindicadores na avaliação de impacto e no monitoramento da contaminação de rios e córregos por agrotóxicos. Ciência \& Saúde Coletiva, v. 12, n. 1, p. 61-72, 2007. https://doi.org/10.1590/s1413-81232007000100011

ASHLEY, P. J. Fish welfare: current issues in aquaculture. Applied Animal Behaviour Science. 104(3-4), 199-235, 2007. https://doi.org/10.1016/j.applanim.2006.09.001

BASTOS, I. C. O.; LOVO, I. C.; ESTANISLAU, C. A. M.; SCOSS, L. M. Utilização de bioindicadores em diferentes hidrossistemas de uma indústria de papeis reciclados em Governador Valadares-MG. Revista Engenharia Sanitária. v.11, p.203- 211, 2006. https://doi.org/10.1590/s1413-41522006000300003

BERNET, D.; SCHIMIDT, H.; MEIER, W.; BURKHARD-HOLM, P.; WAHLI, T. Histophatology in Fish: Proposal for a Protocol to Assess Aquatic Polluition. Journal of Fish Diseases, v. 22, p. 25-34, 1999. https://doi.org/10.1046/j.1365-2761.1999.00134.x

BOLOGNESI, C.; HAYASHI, M. Micronucleus assay in aquatic animals. Mutagenesis, v. 26, p. 205-213, 2011. https://doi.org/10.1093/mutage/geq073

BOMBAIL, V.; DENIS, A. W.; GORDON, E.; BATTY, J. Application of the comet and micronucleus assays to butterfish (Pholis gunnellus) erythrocytes from the Firth of Forth Scotland. Chemosphere, v. 44, p. 383-392, 2001. https://doi.org/10.1016/s0045-6535(00)00300-3

BORTOLUCI, E.; BARUFATTI, A.; OLIVEIRA, J. Y.; CANDIDO, L. Uso de biomarcadores para monitoramento das águas do Córrego Arara no município de Rio Brilhante, MS, Brasil. Ambiente \& Água An Interdisciplinary Journal of Applied Science. 10 (1): 117-129, 2015. https://doi.org/10.4136/ambiagua. 1500

BOSI, G.; ARRIGHI, S.; DI GIANCAMILLO, A.; DOMENEGHINI, C. Histochemistry of glycoconjugates in mucous cells of Salmo trutta uninfected and naturally parasitized with intestinal helminths. Dis. Aquatic Org. 64 (1), p. 45-51, 2005. https://doi.org/10.3354/dao064045

BRASIL. Ministério do Meio Ambiente. Conselho Nacional do Meio Ambiente - CONAMA (2005). Resolução $n^{\circ}$ 357, de 17 de março de 2005. Dispõe sobre a classificação dos corpos d'água e diretrizes ambientais para o seu enquadramento... Diário Oficial da União, Brasília. Disponível em: <http://www.mma.gov.br/port/conama/>. Acesso em: 02 de maio de 2016. https://doi.org/10.17565/gesta.v3i2.15103

BRITO, L. O.; LUZ, L. D. Avaliação e monitoramento da qualidade das águas: usando análises moleculares. Revista Eletrônica de Gestão e Tecnologias Ambientais, v. 3, n. 2, p. 76-90, 2015.

CAJARAVILlE, M. P.; BENIANNO, J. M.; BLASCO, J.; PORTE, C.; SARASQUETE, C.; VIARENGO, A. The use of biomarkers to assess the impact of pollution in coastal environments of the Iberian Peninsula: a practical approach. The Science of the Total Environment, v. 247, n. 2-3, p. 295- 311, 2000.

CANTANHÊDE, S. M.; MEDEIROS, A. M.; FERREIRA, F. S.; FERREIRA, J. R. C.; ALVES, L. M. C.; CUTRIM, M. V. J.; SANTOS, D. M. S. Uso de biomarcador histopatológico em brânquias de Centropomus undecimalis (Bloch, 1972) na avaliação da qualidade da água do Parque Ecológico Laguna da Jansen, São Luís - MA. Arquivo Brasileiro de Medicina Veterinária e Zootecnia. v. 66, n. 2, p. 593-601, 2014. https://doi.org/10.1590/1678-41626348

CARRANO, A. V.; NATARANJAN, S. Considerations for populations monitoring using cytogenetic techniques. Mutation Research, v. 204, p. 379-406, 2002. https://doi.org/10.1016/0165-1218(88)90036-5 
CARRASCO, K. R.; TILBURY, K. L.; MYERS, M. S. Assessment of the piscine micronucleus test as an in situ biological indicator of chemical contaminant effects. Canadian Journal of Fisheries and Aquatic Sciences, v. 47, n. 11, p. 2123-2136, 1990. https://doi.org/10.1139/f90-237

COVELLO, J. M.; BIRD, S., MORRISON, R. N.; BATTAGLENE, S. C.; SECOMBES, C. J.; NOWAK, B. F. Cloning and expression analysis of three striped trumpeter (Latris lineata) pro-inflammatory cytokines, TNF-a, IL-1b and IL-8, in response to infection by the ectoparasitic, Chondracanthus goldsmidi. Fish Shellfish Immunol. 26 (5), p. 773-786, 2009. https://doi.org/10.1016/j.fsi.2009.03.012

DALZOCHIO, T.; SIMÕES, L. A. R.; SOUZA, M. S.; RODRIGUES, G. Z. P.; PETRY, I. E.; ANDRIGUETTI, N. B.; SILVA, G. I. H.; GEHLEN, G.; SILVA, L. B. Water quality parameters, biomarkers and metal bioaccumulation in native fish captured in the Ilha River, southern Brazil. Chemosphere, V. 189, p. 609-618, 2017. https://doi.org/10.1016/j.chemosphere.2017.09.089

FENECH, M.; CHANG, W. P.; KIRSCH-VOLDERS, M.; HOLLAND, N.; BONASSI, S.; ZEIGER, E. HUMN Project: detailed description of the scoring eriteria for the cytokinesis block micronucleus assay using isolated human lymphocyte cultures. Mutation Research, v. 534, n. 1-2, p. 65-75, 2003. https://doi.org/10.1016/s13835718(02)00249-8

FONTÚRBEL-RADA, F. Physicochemical and biological indicators of the eutrophication process at Titikaka Lake (Bolivia). Ecología Aplicada, 4(1-2), 135-141, 2005. https://doi.org/10.21704/rea.v4i1-2.308

FREITAS, C. E. C.; SIQUEIRA-SOUSA, F. K. O uso de peixes como Bioindicador ambiental em áreas de várzeas da Bacia Anazônica. Revista Agrogeoambiental, p.39-44, 2009. https://doi.org/10.18406/2316$1817 \mathrm{v} 1 \mathrm{n} 2200975$

GALINDO, T. P. S; MOREIRA, L. M. Evaluation of genotoxicity using the micronucleus assay and nuclear abnormalities in the tropical sea fish Bathygobius soporator (Valenciennes, 1837) (Teleostei, Gobiidae). Genetics and Molecular Biology. 32: 394-398. 2009. https://doi.org/10.1590/s1415-47572009000200029

GALINDO, T.; SILVA, E.; ROSÁRIO, I. Indução de micronúcleos e toxicidade por efluente doméstico em duas populações de Bathygobius soporator (VALENCIENNES, 1837) (TELEOSTEI, GOBBIDAE) no litoral de Salvador (BA), Brasil. Brazilian Journal of Aquatic Science and Technology, 16(1): 1-7, 2012. https://doi.org/10.14210/bjast.v16n1.p1-7

GRISOLIA, C.; RIVERO, C. L. G.; STARLING, F.; SILVA, I.; BARBOSA, A. C.; DOREA, J. G. Profile of micronucleus frequencies and DNA damage in different species of fish in a eutrophic tropical lake. Genetics and Molecular Biology. 32, 1, 138-143, 2009. https://doi.org/10.1590/s1415-47572009005000009

HINTON, D. E.; LAUREN, D. J. Integrative histopathological approaches to detecting effects of environmental stressors on fishes. In: S. M. ADAMS (Ed) Biological Indicators of Stress in Fish. Bethesda, Maryland: AMERICAN FISHERIES SOCIETY SYMPOSIUM, 1990. p.51-66.

JESUS, T. B.; CARVALHO, C. E. V. Utilização de biomarcadores em peixes como ferramenta para avaliação de contaminação ambiental por mercúrio. Oecologia Brasiliensis, v.12, n.4, p. 680-693, 2008. https://doi.org/10.4257/oeco.2008.1204.07

KELLER, R.; JUSTINO, J.F.; CASSINI, S. T. Assessment of water and seafood microbiology quality in a mangrove region in Vitória, Brazil. Journal of Water and Health, v. 11, n. 3, p. 573-580, 2013. https://doi.org/10.2166/wh.2013.245

LATUF, M. O. Diagnóstico das Águas Superficias do Córrego São Pedro, Juiz de Fora-MG. Geografia Londrina. v. 13. n. 1 - jan./jun. 2004. Disponível em http://www.geo.uel.br/revista>. Acesso em: 15 de janeiro de 2016. https://doi.org/10.4025/bolgeogr.v30i2.10077 
LINS, J. A. P. N.; KIRSCHNIK, P. G.; QUEIROZ, V. S.; CIRIO, S. M. Uso de peixes como biomarcadores para monitoramento ambiental aquático. Revista Acadêmica: Ciências Agrárias e Ambientais, v. 8, n. 4, p. 469-484, 2010. https://doi.org/10.7213/cienciaanimal.v8i4.11018

LUKIN, A.; SHAROVA, J.; BELICHEVA, L.; CAMUS, L. Assessment of fish health status in the Pechora River: effects of contamination. Ecotoxicol. Environ. Saf. 74, p. 355-365, 2011. https://doi.org/10.1016/j.ecoenv.2010.10.022

LUNA, L. G. Manual of histologic staining methods of Armed Forces Institute of Pathology. 3 ed. New York: Mc Graw-Hill Book Company, 1968, 258 p.

LUPI, C.; NHACARINI, N. I.; MAZON, A. F.; SÁ, O. R. Avaliação da poluição ambiental através de alterações morfológicas das brânquias de Oreochromis niloticus (tilápia) nos córregos Retiro, Consulta e Bebedouro, município de Bebedouro - SP. Revista Fafibe on line, n. 3, 2007.

MARCATO, A. C. C.; YABUKI, A. T.; FONTANETTI, C. S. Nickel exposure promotes osmoregulatory disturbances in Oreochromis niloticus gills: histopathological and energy dispersive spectrometry analysis. Environ. Sci. Pollut. Res. 21, p. 13095-13102, 2014. https://doi.org/10.1007/s11356-014-3248-2

MATSUMOTO, S. T.; MANTOVANI, M. S.; MALAGUTTI, R. I. A.; DIAS, A. L.; FONSECA, I. C.; MARIN-MORALES, M. A. Genotoxicity and mutagenicity of water contaminated with tannery effluents, as evaluated by the micronucleus test and come assay using the fish Oreochromis niloticus and chromosome aberrations in onion root-tips. Genetics and Molecular Biology, v.29. p. 148-158, 2006. https://doi.org/10.1590/s1415-47572006000100028

MATSUZAKI, M.; MUCCI, J. L. N.; ROCHA, A. A. Comunidade fitoplanctônica de um pesqueiro na cidade de São Paulo. Saúde Públ., v.38, p.679- 686, 2004. https://doi.org/10.1590/s0034-89102004000500010

MERSCH, J.; BEAUVAIS, M. N; NAGEL, P. Induction of micronucleus in haemocytes and gill cells of zebra mussels, Dressena polymorpha, exposed to clastogens. Mutation Research, v. 371, p. 47-55, 1996.

https://doi.org/10.1016/s0165-1218(96)90093-2

MORESCO, V.; VIANCELLI, A.; NASCIMENTO, M. A.; SOUZA, D. S. M.; RAMOS, A. P. D.; GARCIA, L. A. T.; SIMÕES, C. M. O.; BARARDI, C. R. M. Microbiological and physicochemical analysis of the coastal waters of southern Brazil. Marine Pollution Bulletin, v. 64, n. 1, p. 40-48, 2012.

https://doi.org/10.1016/j.marpolbul.2011.10.026

NIGRO, M.; FALLENI, A.; BARGA, I. D.; SCARCELLI, V.; LUCCHESI, P.; REGOLI, F.; FRENZILLI, G. Cellular biomarkers for monitoring estuarine environments: transplanted versus native mussels. Aquatic Toxicology, v. 77, n. 4, p 339-347, 2006. https://doi.org/10.1016/j.aquatox.2005.12.013

NOGUEIRA, D. J.; CASTRO, S. C.; SÁ, O. R. Avaliação da qualidade da água no reservatório UHE Furnas MG, utilizando as brânquias de Pimelodus maculatus (LACÈPÉDE, 1803) como biomarcador de poluição ambiental. CIÊNCIA ET PRAXIS, 1(1): 15-20, 2008. https://doi.org/10.5007/2175-7925.2011v24n3p51

OLIVEIRA, R. M. M.; SANTOS, E. V. D.; LIMA, K. C. Evaluation of the water quality of São Caetano creek, in Balsas-MA, based on physical, chemical and microbiological parameters. Engenharia Sanitaria e Ambiental, v. 22, n. 3, p. 523-529, 2017. https://doi.org/10.1590/s1413-41522017154657

OMAR, W.A.; ZAGHLOUL, K. H.; ABDEL-KHALEK, A. A.; ABO-HEGAB, S. Genotoxic effects of metal pollution in two fish species, Oreochromis niloticus and Mugil cephalus, from highly degraded aquatic habitats. Mutat. Res./Genet. Toxicol. Environ. Mutagen. 746, 7-14. 2012. https://doi.org/10.1016/j.mrgentox.2012.01.013 
OSMAN, A. G. M., ABD EL REHEEM, A-E-B.; MOUSTAFA, M. A.; MAHMOUD, U. M.; ABUEL-FADL, K. Y.; KLOAS, W. In situ evaluation of the genotoxic potential of the river Nile: I. Micronucleus and nuclear lesion tests of erythrocytes of Oreochromis niloticus (Linnaeus, 1758) and Clarias gariepinus (Burchell, 1822). Toxicol. Environ. Chem. 93, 1002-1017, 2011. https://doi.org/10.1080/02772248.2011.564496

PALHARES, D.; GRISOLIA, C. K. Comparison between the micronucleus frequencies of kidney ang gill erythrocytes in tilapia fish, following mitomyein c treatment. Genetics and Molecular Biology, v. 25, p. 281284, 2002. https://doi.org/10.1590/s1415-47572002000300005

PAULINO, M. G.; SOUZA, N. E. S.; FERNANDES, M. N. Subchronic exposure to atrazine induces biochemical and histopathological changes in the gills of a neotropical freshwater fish, Prochilodus lineatus. Ecotoxicol. Environ. Saf. 80, p. 6-13 2012. https://doi.org/10.1016/j.ecoenv.2012.02.001

PAULINO, M. G.; BENZE, T. P.; SADAUSKAS-HENRIQUE, H.; SAKURAGUI, M. M.; FERNANDES, J. B.; FERNANDES, M. N. The impact of organochlorines and metals on wild fish living in a tropical hydroelectric reservoir: bioaccumulation and histopathological biomarkers. Sci. Total Environ. p. 497-498, 293-306, 2014. https://doi.org/10.1016/j.scitotenv.2014.07.122

PEREIRA. D. P.; SANTOS. D. M. S.; CARVALHO-NETA. A. V.; CRUZ. C. F.; CARVALHO-NETA. R. N. F. Alterações morfológicas em brânquias de Oreochromis niloticus (Pisces, Cichlidae) como biomarcadores de poluição aquática na laguna da Jansen, São Luís, Ma (Brasil). Biosci Journal. v. 30, n. 4, p. 1213-1221, 2014. https://doi.org/10.1590/1678-7414

POLEKSIC, V.; MITROVIC-TUTUNDZIC, V. Fish gills as a monitor of sublethal and chronic effects of pollution. In: MULLER, R.; LLOYD, R. (Ed.). Sublethal and chronic effects of pollutants on freshwater fish. Oxford: FISHING NEWS BOOKS, 1994. p. 339-352.

RIBEIRO, E. B.; BASTOS, L. S.; GALENO, L. S.; MENDES, R. S.; GARINO-JUNIOR, F.; CARVALHONETA, R. N. F.; COSTA, F. N. Integrated assessment of biomarker responses and microbiological analysis of oysters from São Luís Island, Brazil. Marine Pollution Bulletin. v. 113, n. 1, p. 182-186, 2016. https://doi.org/10.1016/j.marpolbul.2016.09.013

ROCHA, P. S.; LUVIZOTTO, G. L.; KOSMEHL, T.; BOETTCHER, M.; STORCH, V.; BRAUNBECK, T.; HOLLERT, H. Sediment genotoxicity in the Tietê River (São Paulo, Brazil): in vitro comet assay versus in situ micronucleus assay studies. Ecotoxicol. Environ. Saf. 72, p.1842-1848, 2009.

https://doi.org/10.1016/j.ecoenv.2009.04.013

RUSSO, C.; ROCCO, L.; MORESCALCHI, M. A.; STINGO, V. Assessment of environmental stress by the micronucleus test and the Comet assay on the genome of teleost populations from two natural environments. Ecotoxicology and Environmental Safety, v. 57, n. 2, p. 168-174, 2004. https://doi.org/10.1016/s0147-6513(03)00027-7

SEISDEDO, M.; DIAZ, M.; BARCIA, S.; ARENCIBIA, G.; CIENFUEGOS, C. P. D. M. Análise comparativa da qualidade da água de dois reservatórios na bacia de Arimao, Cuba (2014-2015). Revista Cubana de Pesquisas Pesqueiras, v. 34, n. 2, p. 0138-8452, 2017. https://doi.org/10.11606/t.6.2016.tde-19072016-170718

SMART, G. The effect of ammonia exposure on gill structure of the rainbow trout (Salmo gairdneri). Journal of Fish Biology, Maiden, v.8, p. 471-475, 1976. https://doi.org/10.1111/j.1095-8649.1976.tb03990.x

SOUZA, T. S.; FONTANETTI, C. S. Micronucleus test and observation of nuclear alterations in erythrocytes of Nile tilapia exposed to waters affected by refinery effluent. Mutation Research/Genetic Toxicology and Environmental Mutagenesis, v. 605, n.1-2, p. 87-93, 2006. https://doi.org/10.1016/j.mrgentox.2006.02.010 
SOUZA, T. S.; FONTANETTI, C. S. Ensaio do cometa para avaliação da qualidade das águas do Rio Paraíba do Sul, numa área sob influência de uma refinaria de petróleo. In: CONGRESSO BRASILEIRO DE PESQUISA E DESENVOLVIMENTO EM PETRÓLEO E GÁS, 4., Campinas, 2007. Anais... Campinas: PDPETRO, 2007. https://doi.org/10.5151/designpro-ped-00274

TAVARES-DIAS, M.; MORAES, F. R. Características hematológicas de Tilapia rendalli Boulenger, 1896 (Osteichthyes: Cichlidae) capturada em "pesque-pague” de França, São Paulo, Brasil. Bioscience Journal, v. 19, n. 01, p. 107-114, 2003.

THOPHON, S.; KRUATRACHUE, M.; UPATHAM, E. S.; POKETHITIYOOK, P.; SAHAPHONG, S.;

JARITKHUAN, S. Histological alterations of white seabass, Lates calcarifer, in acute and subchronic cadmium exposure. Environmental Pollution, v.121, p. 307-320, 2003. https://doi.org/10.1016/s0269-7491(02)00270-1

VON, S. M. Princípios do tratamento biológico de águas residuárias. Belo Horizonte: Universidade Federal de Minas Gerais, 1996. https://doi.org/10.14393/19834071.2016.36163 